общество. И как общественное явление он не стоит на месте, так же, как и визуальные субтитры, которые с каждым днем расширяют свою функциональность и развиваются.

$$
* * *
$$

1. Вахтин Н. Б., Головко Е.В. Социолингвистика и социология языка. СПб., 2004. - 335 с.

2. Мартынова Е. В., Кадырова Л. Б. Некоторые проблемы социолингвистики в современном языкознании // Теоретические и прикладные аспекты современной науки. - Белгород, 2014. № 3-3. - C. $41-43$.

3. Потапова, Д. Н. Лексические особенности субтитров в корейских развлекательных телепрограммах / Д. Н. Потапова // Фундаментальная и прикладная наука: состояние и тенденции развития: сборник статей IV Международной научно-практической конференции, Петрозаводск, 05 апреля 2020 года. - Петрозаводск: Международный центр научного партнерства «Новая Наука», 2020. - С. 175-181.

4. Фельде О. В. Социолингвистика // Эффективное речевое общение (базовые компетенции). Словарь-справочник. Электронное издание под редакцией А. П. Сковородникова. - 2-е издание. Красноярск: Сибирский федеральный ун-т, 2014. - С. 627 - 628.

5. 박지혜. 자막의 효과에 관한 연구: TV 오락프로그램 '상상플러스, 분석을 중심으로. 동아학교, 석사학위논문, 2007. -95 p.

6. 홍종선. "텔레비전 방송 자막의 한글 연구." 우리어문연구, 2010.-31-54 pp.

\title{
Садовникова И.И.
}

\section{Синонимы лексики эмоций в эвенском языке}

ИГИиПМНС СО РАН

(Россия, Якутск)

doi: $10.18411 / l j-07-2021-172$

\section{Аннотация}

Статья посвящена изучению синонимов эмоциональной лексики эвенского языка. Выбор темы обусловлен тем, что исследования лексической синонимии недостаточно изучены, так как в эвенском языке вопросы синонимии рассматривались лишь эпизодически в рамках работ по лексикологии, затрагивали данную тему в учебниках и учебных пособиях. Результаты данной работы послужат фундаментом для дальнейших исследований синонимии эвенского языка.

Ключевые слова: эвенский язык, синонимы, лексика, эмоции.

\section{Abstract}

The article is devoted to the study of synonyms of the emotional vocabulary of the Even language. The choice of the topic is due to the fact that the research of lexical synonymy is not sufficiently studied in the Even language, since in the Even language the issues of synonymy were considered only occasionally in the framework of works on lexicology, they touched on this topic in textbooks and textbooks on the Even language. The results of this work will serve as a foundation for further studies of the synonymy of the Even language.

Keywords: even language, synonyms, vocabulary, emotions.

Научная новизна работы заключается в следующем: проводится лексическое описание эмотивного фонда эвенского языка; впервые выявляются и анализируются синонимические ряды; при анализе синонимического аспекта эмотивной системы учитывается полный набор лексических наименований эмоций; исследуется языковой материал, до настоящего времени почти не изучавшийся лингвистами эвенского языка синонимическими единицами со значением радости и печали. Теоретическая значимость заключается в обобщении данных об основных понятиях и выявлению синонимических пар эмоций в эвенском языке. Практическая значимость. 
Представленные в работе синонимические ряды эмоций человека, могут быть использованы при составлении синонимического словаря и учебных пособий.

Необходимость сбора, исследования синонимов эмотивной лексики эвенского языка вызвана тем, что синонимы недостаточно изучены в эвенском языке, так как в эвенском языкознании вопросы синонимии рассматривались лишь эпизодически в рамках работ по лексикологии, затрагивали данную тему в учебниках и учебных пособиях по эвенскому языку.

Синонимы - это слова, тождественные по своему значению, выражающие одни и те же понятия, но различающиеся по звуковому составу. Синонимы играют важную роль в речи. Они разнообразят ее, делают речь более образной, выразительной, дают возможность выражать оттенки мысли. [5, с. 36,37].

Свою точку зрения синонимии излагает А.П. Евгеньева: «Тождественными и близкими по значению следует считать только те слова, которые употребляются для обозначения одного и того же понятия и различаются между собой или оттенками значения в пределах данного понятия, или экспрессивной эмоциональной окраской, или употреблением в определённых стилистических условиях, в определённых сочетаниях с теми или иными словами» $[1, \mathrm{c.10}]$.

Психолог К. Изард включает в мотивационную систему человека 10 фундаментальных эмоций: интерес, радость, удивление, горе, гнев, отвращение, презрение, страх, стыд, вина [2]. Основываясь на этом списке, будут описаны синонимы эмотивной лексики, под которыми понимается одинаковое логическое содержание, но с противоположной или различной эмоциональной оценкой. В эвенском языке много слов, образующих многочисленные синонимические ряды, которые выражают внутреннее состояние и переживание человека. В связи с этим внутри классов лексика должна быть распределена по группам:

Эмоциональное состояние: мулиньдай $\sim$ авдаттай $\sim$ хэкуруңчидэй $\sim$ мэргэттэй $~$ авуландай “беспокоиться"; дуялдай иркалдай кунидай “закричать”, “заорать”; хокаңчидай $\sim$ өрэлдэй $\sim$ өрустэй $\sim$ эвэлдэй “радоваться"; китэңчидэй $\sim$ хиралдай $~$ тикулдай “сердиться”, “разозлиться”; ининдэй хаңчидай мясаматтай “смеяться”; нес мурач талан хэнэ дюл "счастье", “удача"; мэргэчин набус "печаль"; нусартадай $\sim$ хоңдай $\sim$ богордай зап. “плакать”; аручин $\sim$ нюмарин $\sim$ хадарин $\sim$ халдюн “стыд”, “смущение”; нэлукэттэй кастай “внушить страх"; хэлэдэй $\sim$ хуктэй муладай “сожалеть"; хэчус анда хилус "мучительно"; тикун хэлэмэк “ненависть”; чакрун эечин "зависть"; асан $\sim$ хенңан $\sim$ өнсэн “обида"; гэлэн $\sim$ булун $\sim$ хөркэнь $\sim$ хонрин “грусть”, “тоска" и т.д.

Становление эмоционального состояния: авдачилдай $~$ хэкурунчилдэй мэргэчилдэй “забеспокоиться”; гитэрчидэй банурудай “заупрямиться”; өрэлдэдэй хокаңчилдай “развеселиться”; олалдадай нэлэлдэй “испугаться”; гэлэлдэй булулдай “загрустить”; ханьканалдай песен. хокаңчилдай $~$ өрэлдэдэй $\sim$ өрусэлдэй эвэлдэдэй "обрадоваться"; асанни өнинни "обидеться"; муядай тикулдай "выходить из терпения", “разгневаться"; хакудай набуттай булукандай “опечалиться"; хадарилдай нюмарилдай $\sim$ халдюналдай “засмущаться” и.т.д.

Эмоциональное воздействие: авуняси бурдэне обращение “к человеку, причиняющему беспокойство", хирукандай тикумкаттай “вывести из себя"; оламкандай нэлукэндэй “испугать кого-л.”; асукандай өнинмэдэй “обидеть когол.”; хадаривкандай нюмаримкандай халдювкаттай “стыдить кого-л.” и.т.д.

Эмоциональное отношение: булукандай набукандай “опечалить кого-либо”, гадидай песен. - аявалдай “полюбить”; мэргэттэй мулгадай дёмкаттай “думать, беспокоиться о ком-л.”; илрандай гудендэй “жалеть кого-л.”, дабдандай $~$ чакрундай “испытывать зависть к кому-л.”, эелдэй аявалукандай “заинтересоваться кем-л.”; урлидай чармидай “ревновать кому-л.” и т.д. 
Внешнее выражение эмоций: бокутнадай хэритнэлдэй “захлебываться от волнения, быть в сильном волнении"; ининэлдэй хаңчилдай “засмеяться”; булдай хоңукандай "пустить слезу"; дяргадай налдамадай “обзываться"; наргаматтай нэимэттэй элгимэттэй “ругаться"; дяюттай $~$ хумэттэй “утаивать”; муядай $\sim$ хирдай "злиться, выходить из терпения"; наргадай $\sim$ киргэдэй “рычать от злости, рассердившись (о человеке)"; нэлэлдэй нюмэриндэй “испугаться"; аюрчидай одукаттай ирэмкэттэй “успокаивать”, “утешать”; болдандай бэлтэндэй “вытаращить глаза”; тилбардай чалбундай “ выражать чувство отвращения”; комняматтай натиматтай “корчить гримассу” и т.д.

Эмоциональная характеристика: эетмэин дабданя “завистник”; гэлэвкэ набанңа "грустный”; эвэч хэбдень “веселый”; хэңунтэ нэлэтэ “боязливый”; бады дяги "бесстыжий”; нюмарита хадарилкан “застенчивый” и т.д.

Эмоциональное качество: гуден $\sim$ илран $\sim$ хэлэн “жалость"; дэвсэнь $\sim$ хэритнэн "волнение"; асан өнсэн "обида"; булун гэлэн "тоска"; нюмар хадарин “стыд" и т.д.

Подводя итоги нашему небольшому исследованию, необходимо отметить, что в эвенском языке существуют различные синонимические ряды эмоций, имеющие свою специфику способы проявления, которые образуют эмотивную лексику эвенского языка.

$$
* * *
$$

1. Евгеньева А.П. Словарь синонимов русского языка: в 2-х т. Л.: Наука, 1970. Т. 1-2. С. 656.

2. Изард, К.Э. Психология эмоций [Текст] / К.Э. Изард, пер. с англ. - СПб.: Питер, 1999. — 464 с.

3. Левин В.И. Краткий эвенско-русский словарь. - Л.: Учпедгиз, 1936.

4. Новикова К.А., Гладкова Н.И., Роббек В.А. Эвенский язык: Учеб. для пед. Уч-щ. Л.: Просвещение. 1991. C.304.

5. Палевская М.Ф. Синонимы в русском языке. М.: Просвещение, 1964. С. 128.

6. Ришес Л.Д. Русско-эвенский словарь для эвенской начальной школы. - Л.: Учпедгиз, 1950.

7. Роббек В.А., Роббек М.Е. Эвенско-русский словарь. - Н.: Наука, 2004. - С. 356.

\section{Ситникова О.А. \\ Американский и британский английский: сходства и различия}

Белгородский государственньй национальный исследовательский университет (Россия, Белгород)

doi: $10.18411 / \mathrm{lj}-07-2021-173$

\section{Аннотация}

Будучи одним из самых популярных языков, английский имеет множество разновидностей. На английском говорят люди, населяющие США, Индию, Пакистан, Великобританию, Германию, Канаду, Австралию и Индию. Однако в первую очередь носители английского ассоциируются с Великобританией и Соединенными Штатами. Говоря о степени родства и различия между британским и американским английским, нельзя не вспомнить слова Джорджа Бернарда Шоу о том, что Соединённые Штаты и Великобритания - две страны, разделённые общим языком. Таким образом, наша статья посвящена разнице между британским и американским английским.

Ключевые слова: американский английский, британский английский, фонетика, грамматика, лексика.

\section{Abstract}

Being one of the most popular languages, English has many varieties. English is spoken by people living in the United States, India, Pakistan, Great Britain, Germany, Canada, Australia, and India. However, native English speakers are primarily associated with 